\title{
Model Development of Behavior-Based Safety in Workplace Based on Religiosity and Psychological Condition of Workers at PT. Semen Tonasa
}

\author{
Atjo Wahyu ${ }^{1}$, Tjipto Suwandi ${ }^{2}$, Hari Basuki ${ }^{3}$, Anwar Mallongi $^{4 *}$ \\ ${ }^{1}$ Department of Occupational Health and Safety, Faculty of Public Health, Hasanuddin University, South Sulawesi 90245, \\ Indonesia; '2Department of Occupational Health and Safety, Faculty of Public Health, Airlangga University, East Java 60115, \\ Indonesia; ${ }^{3}$ Department of Biostatistics, Faculty of Public Health, Airlangga University, East Java 60115, Indonesia; ${ }^{4}$ Department \\ of Environmental Health, Faculty of Public Health, Hasanuddin University, South Sulawesi 90245, Indonesia
}

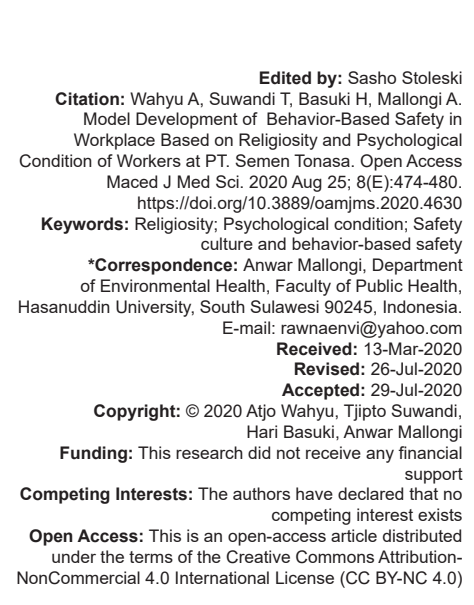

Introduction

Safety behavior structural equation model perceived in nuclear power plants [1]. Leadership has an influence on safety climate and the influence impacts on safety behavior. Safety culture directly affects safety climate and safety behavior. Several studies that have been conducted aimed to improve behavior in the workplace but these studies have not examined the role of religiosity in the workplace.

The production process of PT. Semen Tonasa involves a numbers of human labors. The process uses cutting edge technology, hazardous equipment or machines, and substances which are very risky to cause accidents. The number of occupational accidents in PT. Semen Tonasa from 2000 to 2005 was recorded as many as 71 cases. In 2000, the number of occupational accidents was recorded as many as 16 cases, 10 cases were recorded in 2001, 12 cases were recorded in 2002, 8 cases were recorded in 2003, 9 cases were recorded in 2004, and there were 16 cases in 2005.

A study conducted by Fajriani shows that the awareness to use personal protective equipment is still very low, there are still around $(22.2 \%)$ of workers who do not use personal protective equipment at the time of work.

According to data from the Health and Safety of PT. Semen Tonasa, the loss due to occupational accidents such as loss of working days during the period of 2000-2005 was 14.465 working days. In 2000 , the loss was 13.186 week days, as many as 366 working days in 2001, as many as 523 working days in 2002 , as many as 236 working days in 2003 , as many as 88 working days in 2004, and as many as 66 working days in 2005.

Given the magnitude of losses incurred as a result of occupational accidents, accidents or potential accidents at the workplace should be prevented and the negative impacts should be reduced. One is to apply 
the behavior-based safety [2], [3], [4]. This is intended to make the workers and every person in the workplace are always health and safe, the productive resources can be used efficiently, and the production process can run smoothly in accordance with the goals and objectives of the safety. Behavior-based safety model applied in various industries has not been effective and its implementation in the field is still inadequate field. This makes the numbers of occupational accidents and the amount of losses due to the accidents at work still fluctuating. Based on the facts above, this research will develop behavioral based safety with religiosity approach and psychological condition at the workplace.

\section{Materials and Methods}

This research used survey research method, in which the data were obtained from a population questionnaire from health department. Based on the time dimension, this research used cross-sectional design to analyze the dynamics of the correlation between exogenous and endogenous variables by means of observation or point time approach. This is an explanatory research as it is based on the perception of the respondents and it explains the causal relationship between variables based on the respondents' answer through hypothesis testing. The population of the research was all workers (267 workers) at the slag production unit I (147 workers) and slag production unit II (120 workers) in Semen Tonasa Industry.

The sample size was 158 workers consisting of 87 workers at the slag production unit I and 71 workers at the slag production unit II.

\section{Inclusion criteria}

1. Having at least 1 year work experience.

2. Willing to be a respondent during the research process.

Samples were taken through proportional random sampling in each production slag unit. To examine the correlation of the research, structural equation modeling analysis technique with Lisrel is used. If t-value $>1.96$ (alpha $5 \%$ ), it means that the test is significant, and vice versa if the t-value $<1.96$ (alpha $5 \%$ ), it means that the test is not significant.

\section{Results}

\section{Psychological condition}

Psychological indicators are perception, attitude, personality, learning, and motivation. The level of psychological condition of the workers at Slag Production Department of PT. Semen Tonasa is shown in Table 1 as follows.

Table 1: Distribution of the responses of the respondents to indicators of psychology

\begin{tabular}{|c|c|c|c|c|c|c|c|c|}
\hline \multirow{3}{*}{$\begin{array}{l}\text { Indicators of } \\
\text { psychological } \\
\text { condition }\end{array}$} & \multicolumn{6}{|c|}{ Respondents } & \multirow{2}{*}{\multicolumn{2}{|c|}{ Number }} \\
\hline & \multicolumn{2}{|c|}{ High } & \multicolumn{2}{|c|}{ Moderate } & \multicolumn{2}{|c|}{ Low } & & \\
\hline & $\mathrm{n}$ & $\%$ & $\mathrm{n}$ & $\%$ & $\mathrm{n}$ & $\%$ & $\mathrm{n}$ & $\%$ \\
\hline Perception & 29 & 18.4 & 94 & 59.5 & 35 & 22.2 & 158 & 100.0 \\
\hline Attitude & 23 & 14.6 & 112 & 70.9 & 23 & 14.6 & 158 & 100.0 \\
\hline Personality & 19 & 12.0 & 117 & 74.1 & 22 & 13.9 & 158 & 100.0 \\
\hline Learning & 23 & 14.6 & 114 & 72.2 & 21 & 13.3 & 158 & 100.0 \\
\hline Motivation & 38 & 24.1 & 102 & 64.6 & 18 & 11.4 & 158 & 100.0 \\
\hline
\end{tabular}

Table 1 shows that the high response of workers to perception is as many as 29 people $(18.4 \%)$, moderate response is as many as 94 people $(59.5 \%)$, and low response is as many as 35 people $(22.2 \%)$. The high response of workers to attitude is as many as 23 people (14.6\%), moderate response is as many as 112 people $(70.9 \%)$, and low response is as many as 22 people (13.9\%). The high response of workers to personality is as many as 19 people (12\%), moderate response is as many as 117 people $(74.1 \%)$, and low response is as many as 22 people $(13.9 \%)$. The high response of workers to learning is as many as 23 people (14.6\%), moderate response is as many as 114 people $(72.2 \%)$, and low response is as many as 21 people (13.3\%), while the high response of workers to motivation is as many as 38 people $(24.1 \%)$, moderate response is as many as 102 people $(64.6 \%)$, and low response is as many as 18 people $(11.4 \%)$.

Indicators that affect the psychological conditions at Slag Production Department of PT. Semen Tonasa are shown in Table 2.

Table 2: Results of loading factor of each indicator of psychological conditions

\begin{tabular}{llllll}
\hline Indicators of psychology & $\lambda$ & $\mathrm{t}_{\lambda}$ & $1-\delta$ & $\mathrm{t}_{1-\delta}$ & Remarks \\
\hline Perception (W1) & 0.80 & 13.20 & 0.36 & 5.16 & Valid and reliable \\
Attitude (W2) & 0.62 & 9.17 & 0.61 & 7.76 & Valid and reliable \\
Personality (W3) & 0.73 & 10.93 & 0.47 & 5.74 & Valid and reliable \\
Learning (W4) & 0.79 & 11.73 & 0.38 & 6.57 & Valid and reliable \\
Motivation (W5) & 0.31 & 3.71 & 0.91 & 8.06 & Valid and reliable \\
\hline
\end{tabular}

Based on the results of the estimation of the standardized solution and $t$ value of Lisrel above, it can be seen that most loading actors of all indicators of psychological condition are $>0.50$. Thus, it can be concluded that all indicators are valid. The value for $1-\delta$ and the value of $\lambda$ of all indicators have $t$ values above 1.96. It means that all indicators of psychological condition are reliable. It can be seen that the results of goodness of fit model are also good.

\section{Safety culture}

Indicators of safety culture are as follows: Commitment, rules and procedures, communication, competence, work environment, and involvement. Safety culture of the workers at Slag Production Department of PT. Semen Tonasa is shown in Table 3 as follows. 
Table 3: Distribution of responses of the respondents to the indicators of safety culture

\begin{tabular}{|c|c|c|c|c|c|c|c|c|}
\hline \multirow{3}{*}{$\begin{array}{l}\text { Indicators of safety } \\
\text { culture }\end{array}$} & \multicolumn{6}{|c|}{ Respondents } & \multirow{2}{*}{\multicolumn{2}{|c|}{ Total }} \\
\hline & \multicolumn{2}{|c|}{ High } & \multicolumn{2}{|c|}{ Moderate } & \multicolumn{2}{|c|}{ Low } & & \\
\hline & $\mathrm{n}$ & $\%$ & $\mathrm{n}$ & $\%$ & $\mathrm{n}$ & $\%$ & $\mathrm{n}$ & $\%$ \\
\hline Commitment & 23 & 14.6 & 113 & 71.5 & 22 & 13.9 & 158 & 100 \\
\hline Rules and procedures & 37 & 23.4 & 101 & 63.9 & 20 & 12.7 & 158 & 100 \\
\hline Communication & 24 & 15.2 & 110 & 69.6 & 24 & 15.2 & 158 & 100 \\
\hline Competence & 27 & 17.1 & 117 & 74.1 & 14 & 8.9 & 158 & 100.0 \\
\hline Work environment & 24 & 15.2 & 116 & 73.4 & 18 & 11.4 & 158 & 100.0 \\
\hline Involvement & 26 & 16.5 & 101 & 63.9 & 31 & 19.6 & 158 & 100.0 \\
\hline
\end{tabular}

Table 3 shows that the high response of workers to commitment is as many as 23 people (14.6\%), moderate response is as many as 113 people $(71.5 \%)$, and low response is as many as 22 people (13.9\%). The high response of workers to rules and procedures is as many as 37 people $(23.4 \%)$, moderate response is as many as 102 people $(63.3 \%)$, and low response is as many as 20 people $(12.7 \%)$. The high response of workers to communication is as many as 24 people (15.2\%), moderate response is as many as 110 people $(69.6 \%)$, and low response is as many as 24 people (15.2\%). The high response of workers to competence is as many as 27 people $(17.1 \%)$, moderate response is as many as 117 people (74.1\%), and low response is as many as 14 people (8.9\%). The high response of workers to work environment is as many as 24 people (15.2\%), moderate response is as many as 116 people $(73.4 \%)$, and low response is as many as 18 people (11.4\%), while the high response of workers to involvement is as many as 26 people $(16.5 \%)$, moderate response is as many as 101 people $(63.9 \%)$, and low response is as many as 31 people $(19.6 \%)$. Indicators that affect safety culture at Slag Production Department of PT. Semen Tonasa are shown in Table 4 as follows.

Table 4: Loading factor of each indicator of safety culture

\begin{tabular}{llllll}
\hline Indicators of safety culture & $\wedge$ & $\mathrm{t}_{\lambda}$ & $1-\delta$ & $\mathrm{t}_{1-\delta}$ & Remarks \\
\hline Commitment (X1) & 0.81 & 12.70 & 0.34 & 7.10 & Valid and reliable \\
Rules and procedures (X2) & 0.70 & 10.57 & 0.51 & 7.79 & Valid and reliable \\
Communication (X3) & 0.72 & 10.79 & 0.48 & 6.52 & Valid and reliable \\
Competence (X4) & 0.68 & 9.99 & 0.54 & 5.21 & Valid and reliable \\
Working environment (X5) & 0.78 & 9.99 & 0.40 & 3.96 & Valid and reliable \\
Involvement (X6) & 0.74 & 12.26 & 0.45 & 6.84 & Valid and reliable \\
\hline
\end{tabular}

Based on the results of the standardized solution and $t$ value of Lisrel above, it can be seen that most loading factors of all indicators of safety culture are $>0.50$. Thus, it can be concluded that all indicators are valid. The value for $1-\delta$ and the value of $\lambda$ of all indicators have $t$ values above 1.96 . It means that all indicators of safety culture are reliable. It can be seen that the results of goodness of fit model are also good.

\section{Knowledge and attitude}

Indicators of knowledge and attitude of health and safety (K3) are knowledge and attitude. Knowledge and attitude of health and safety (K3) of workers at Slag Production Department of PT. Semen Tonasa are shown in Table 5 as follows.
Table 5: Distribution of responses of the respondents to the indicators of knowledge and attitude on health and safety

\begin{tabular}{|c|c|c|c|c|c|c|c|c|}
\hline \multirow{3}{*}{$\begin{array}{l}\text { Indicators of knowledge } \\
\text { and attitude on } \mathrm{K} 3\end{array}$} & \multicolumn{6}{|c|}{ Respondents } & \multirow{2}{*}{\multicolumn{2}{|c|}{ Total }} \\
\hline & \multicolumn{2}{|c|}{ High } & \multicolumn{2}{|c|}{ Moderate } & \multicolumn{2}{|c|}{ Low } & & \\
\hline & $n$ & $\%$ & $\mathrm{n}$ & $\%$ & $\mathrm{n}$ & $\%$ & $\mathrm{n}$ & $\%$ \\
\hline Knowledge & 36 & 22.8 & 102 & 64.6 & 20 & 12.7 & 158 & 100.0 \\
\hline Attitude & 32 & 20.3 & 108 & 68.4 & 18 & 11.4 & 158 & 100.0 \\
\hline
\end{tabular}

Table 5 shows that the high response of workers to knowledge is as many as 36 people (22.8\%), moderate response is as many as 102 people $(64.6 \%)$, and low response is as many as 20 people (12.7\%). The high response of workers to attitude is as many as 32 people $(20.3 \%)$, moderate response is as many as 108 people $(68.4 \%)$, and low response is as many as 18 people $(11.4 \%)$.

\section{Behavior-based safety}

Indicators of behavior-based safety are as follows: Identification, communication, observation, and feedback. Behavior-based safety of workers at Slag Production Department of PT. Semen Tonasa is shown in Table 6 as follows.

Table 6: Distribution of responses of the respondents to indicators of behavior-based safety

\begin{tabular}{|c|c|c|c|c|c|c|c|c|}
\hline \multirow{3}{*}{$\begin{array}{l}\text { Indicators of Behavior- } \\
\text { based safety }\end{array}$} & \multicolumn{6}{|c|}{ Respondents } & \multirow{2}{*}{\multicolumn{2}{|c|}{ Total }} \\
\hline & \multicolumn{2}{|c|}{ High } & \multicolumn{2}{|c|}{ Moderate } & \multicolumn{2}{|c|}{ Low } & & \\
\hline & $\mathrm{n}$ & $\%$ & $\mathrm{n}$ & $\%$ & $\mathrm{n}$ & $\%$ & $\mathrm{n}$ & $\%$ \\
\hline Identification & 40 & 25.3 & 97 & 61.4 & 21 & 13.3 & 158 & 100.0 \\
\hline Communication & 47 & 29.7 & 90 & 57 & 21 & 13.3 & 158 & 100.0 \\
\hline Observation & 10 & 6.3 & 120 & 75.9 & 28 & 17.7 & 158 & 100.0 \\
\hline Feedback & 29 & 18.4 & 103 & 65.2 & 26 & 16.5 & 158 & 100.0 \\
\hline
\end{tabular}

Table 6 shows that the high response of the workers to identification is as many as 40 people $(25.3 \%)$, moderate response is as many as 97 people $(61.4 \%)$, and low response is as many as 21 people (13.3\%). The high response of workers to communication is as many as 47 people $(29.7 \%)$, moderate response is as many as 90 people (57\%), and low response is as many as 21 people (13.3\%). The high response of the workers to observation is as many as 10 people $(6.3 \%)$, moderate response is as many as 120 people $(75.9 \%)$, and low response is as many as 28 people $(17.7 \%)$, while the high response of workers to feedback is as many as 29 people (18.4\%), moderate response is as many as 103 people $(65.2 \%)$, and low response is as many as 26 people (16.5\%). The indicators that can affect the safety culture at Slag Production Department of PT Semen Tonasa are shown in Table 7 as follows.

Table 7: Results of loading factor of each indicator behavior

\begin{tabular}{lllllll}
\hline Behavior & Indicator & $\wedge$ & $\mathrm{t}_{\lambda}$ & $1-\delta$ & $\mathrm{t}_{1-\delta}$ & Remarks \\
\hline Knowledge & Knowledge (Y1) & 0.83 & 9.61 & 0.31 & 2.54 & Valid and reliable \\
and attitude & Attitude (Y2) & 0.72 & 4.33 & 0.48 & 1.60 & Valid and reliable \\
BBS & Identification (Z1) & 0.78 & 8.29 & 0.46 & 4.58 & Valid and less reliable \\
practice & Communication (Z2) & 0.69 & 7.22 & 0.52 & 3.51 & Valid and reliable \\
& Observation (Z3) & 0.76 & 8.52 & 0.43 & 3.79 & Valid and reliable \\
& Feedback (Z4) & 0.74 & 11.85 & 0.45 & 6.61 & Valid and reliable \\
\hline BBS: Behavior-based safety. & & & & &
\end{tabular}

Based on the results of the estimation of standardized solution and $t$ value of Lisrel above, it can be seen that most loading factors of all indicators of attitude are $>0.50$. Thus, it can be concluded that all 
indicators are valid. The value for $1-\delta$ and the value of $\lambda$ of all indicators have $t$ values above 1.96. It means that all indicators of attitude are reliable. It can be seen that the results of goodness of fit model are good.

\section{Discussion}

\section{Behavior-based safety model based on the level of religiosity and psychological conditions of the workers}

\section{Evaluation of measurement model (outer model)}

The technique of data analysis used in this research is Lisrel. Analysis of the results of Lisrel was performed by evaluating structural equation model. There are two basic evaluations, namely, (1) the evaluation of the measurement model (outer model) to determine the validity and reliability of indicators that measure the latent variables and (2) evaluation of structural model (inner model) to determine the model constancy. Before model evaluation, it can be reiterated that the research instrument as a means of data collection is a valid and reliable instrument.

Evaluation of the measurement model examines the validity and reliability of indicator that measures latent variable. Latent variables of the research are safety culture $(X)$, knowledge and attitude on $\mathrm{K} 3(\mathrm{Y})$, behavior-based safety $(\mathrm{Z})$, psychological conditions (W), and the level of religiosity (V).

Convergent validity measures the validity of indicator which can be seen from the loading factor. Indicator is considered valid if the value of outer loading is above 0.5 and/or the value of t-statistic is above 1.96 . The value of outer loading can also be interpreted as the contribution of each indicator to the latent variable. Loading factor of an indicator with the highest value means that the indicator is the strongest measure of the latent variable in question.

The test analysis results of the behaviorbased safety model based on the level of religiosity and psychological conditions of workers are shown in Figure 1 and Table 2 as follows.

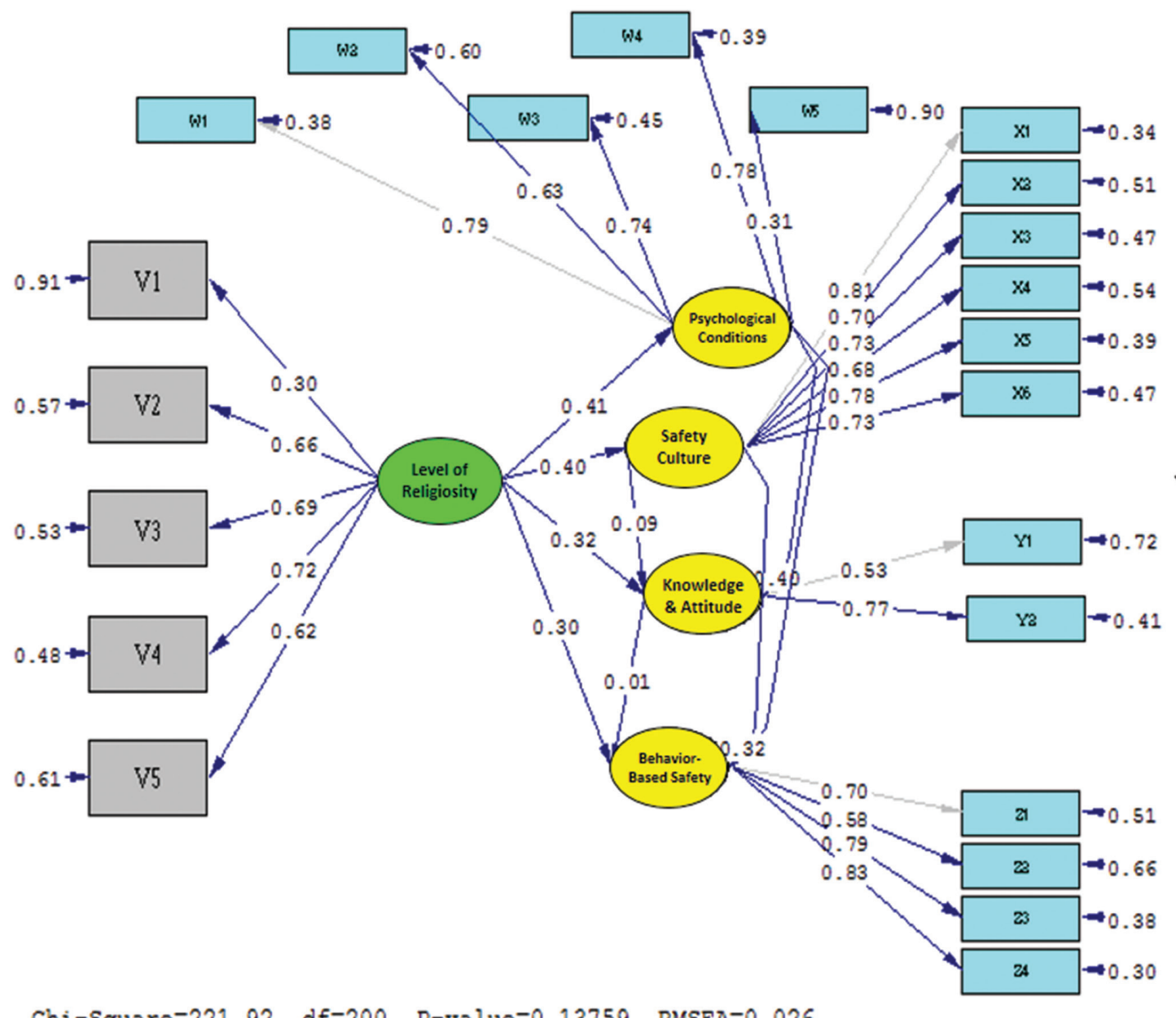

Chi-Square $=221.92, d f=200, p-v a l u e=0.13759, \quad$ MSEA $=0.026$ 


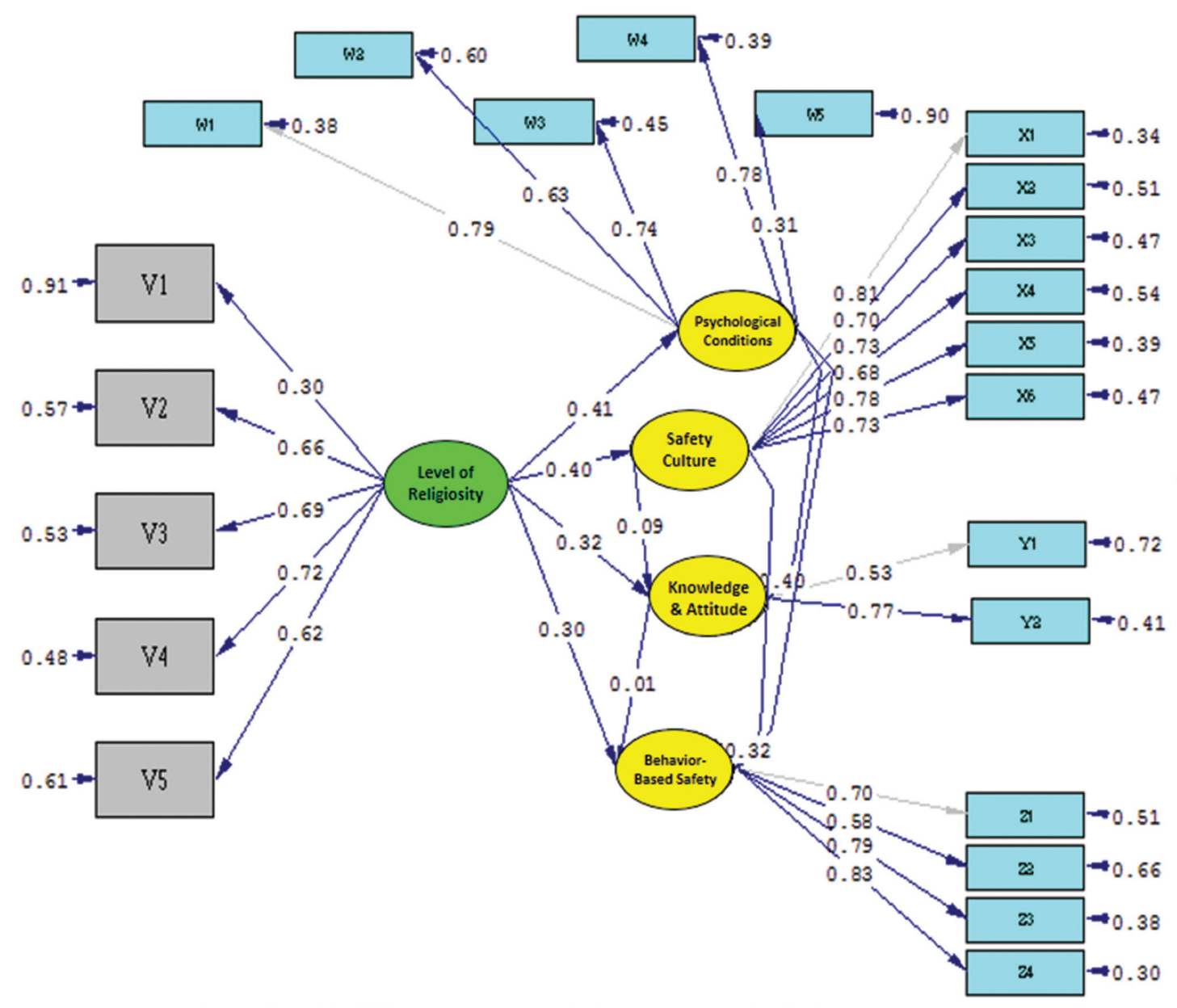

Chi-Square $=221.92, d f=200, p-v a l u e=0.13759$, RMSEA $=0.026$

Figure 1: Test analysis of standardized solution model

\section{The effect of religiosity on behavior-based} safety

This research showed that there was a significant effect of religiosity level on psychological conditions of workers. It is known that all indicator variables of religiosity levels (religious belief, religious practice, religious feeling, religious knowledge, and religious effect) were at middle level, namely, 56.3$62 \%$, with a loading factor above 0.5 . It also showed that behavior-based safety (identification, communication, observation, and feedback) was also at middle level, namely, 52.0-79.8, and with a loading factor above 0.5.

Similarly, Krisnaldi [5] suggested that religiosity is an individual's ability to adjust to the outside world and execute, practice, or apply the system of values or beliefs correctly based on faith and devotion. For succeeding behavior-based safety program, all employees, from top management to the lower levels of workers, should be involved. The behavior-based safety program, however, is not based on assumptions, personal feelings, and/or general knowledge, but its implementation should be based on scientific knowledge. Therefore, behaviorbased safety can reflect a proactive approach to safety and health focusing on risky behaviors that can lead to injury. Thus, its focus is on safe behaviors that can contribute to the prevention of accidents [6], [7]. The findings of this research then showed that there was a significant relationship between religiosity level and behavior-based safety. This result was also supported by several researches that individual behavior in a work could be caused by a sense of religiosity improving the ethical behavior [8]. Thus, increasing ethical behavior is expected to make objectives achieved and satisfying as the initial objectives.

Furthermore, Fauzan [8] argued that religion as moral teaching formed certain personalities, such as honesty, discipline, solidarity, optimism, enthusiasm, and tolerance. Thus, it is believed that one's religiosity has a significant role to pump up his spirits in business activity. In the same way, Weaver and Agle conducted a research based on a literature about symbolic interactions perspective. In this research, they discussed the relationship between religiosity and ethical behavior in organizations [8].

In addition, religious sensitivity was a factor forming consumer behavior (Febby Indra Firman, [9]). Furthermore, Fauzan [8] concluded that (1) religiosity or religious sense: Although it was not dominant, it could still influence behavior, (2) business practices based 
on ethical behavior based on the religious values and teaching, and (3) ritual was a variable that affected the behavior of business ethics. Brow et al. [10], moreover, said that religiosity provided a substantial contribution in shaping ethical behavior in business. Based on the facts, theories, and research findings that have been presented above, we can finally conclude that there is significant positive effect of religiosity level on behaviorbased safety [8], [9], [10].

\section{The effect of psychological condition on behavior-based safety}

This research showed that there was a significant effect of psychological condition of workers on behaviorbased safety. It is known that psychological conditions of workers consisting of five indicators (perceptions, attitudes, personality, learning, and motivation) were at middle level, about 59.5-74.1, with a loading factor above 0.5 . It also showed that behavior-based safety that consists of four indicators (identification, communication, observation, and feedback) was also at middle level, about 52.0-79.8, with a loading factor above 0.5.

In addition, it is believed that psychological factor involves the growth and movement of human consciousness because of external influence in the form of behaviors or actions in fulfilling their needs. Moreover, it is also known that psychological factors also play an important role in increasing the efficiency and productivity of work because it involves human consciousness and behavior in facing duties and obligations [11].

Geller [12] also explained that to change critical behavior, it was necessary to focus on overt behavior. Behavior change occurs through learning process. The learning process occurs best when it can produce a relatively permanent change in behavior. Human behavior is the reflection of various psychological factors, such as knowledge, desire, interest, emotion, will, thought, motivation, perception, attitudes, reactions, and so forth.

Therefore, this research found that there was a significant influence of the psychological conditions of workers on behavior-based safety. This is also supported with a research conducted by Dewi [13] who found that there was the effect of the perception and behavior of non-medical and paramedical workers on the application of safety in hospitals. Furthermore, a research conducted by Saputra [14] also found that there was a relationship between health and safety training (K3), safety motivation, health and safety climate (K3), the roles of working and employers, and the safe behavior of workers as drivers.

Furthermore, Siska [15] also examined psychological factors (motivation, perception, learning, beliefs, and attitudes) affecting consumer behavior at PT Bank Muamalatin Pekanbaru, Indonesia. The results of this research concluded that motivation was the most dominant variable influencing consumer behavior.

\section{The effects of knowledge and attitudes of behavior-based safety}

This research showed that there was no significant effect of knowledge and attitudes of behaviorbased safety. It is also known that knowledge and attitudes related with the health and safety of workers consisting of two indicators (knowledge and attitudes) were at middle level, about 64.6-68.4, with a loading factor above 0.5 . It also showed that behavior-based safety consisting of four indicators (identification, communication, observation, and feedback) was also at middle level, about 52.0-79.8, with a loading factor above 0.5 .

Moreover, this research found that there was no significant effect of knowledge and attitudes of behavior-based safety. Based on the previous theories, it is known that knowledge and attitudes could affect one's actions, but some of the facts found in several research results were not in accordance with it. More detail can be described in several researches as follows: It is supported by a research conducted by Siti [16] who found that there was a relationship between the level of knowledge and healthy eating behavior in students, but Dahlawy [17] also found that there was no relationship between attitude and behavior of occupational health and safety (K3) in the processing area of PT. Antam Tbk. In addition, a research about nursing at the hospital also explained that there was a relationship between individual, psychological, and organizational characteristics and nursing care documenting behavior at inpatient unit [18].

Based on the facts and theories as well as the research that have been presented above, we may say that there was theoretically no significant effects of knowledge and attitudes of behavior-based safety. $H$, based on some of researches, the relationship between attitudes and knowledge was not always linear and not necessarily related to one another. This may be due to the actions or behaviors that are influenced very much. Similarly, the findings of this research also concluded that there was no significant effect of knowledge and attitudes of behavior-based safety. This is most likely due to that the behavioral based safety is also directly influenced by religiosity level of workers, psychological conditions, and safety culture.

\section{Conclusion}

1. Religiosity has a positive effect on the improvement of the psychological conditions of workers in PT. Semen Tonasa. 
2. Religiosity has a positive effect on the improvement of the knowledge and attitude of workers in PT. Semen Tonasa.

3. Religiosity has a positive effect on the improvement of safety culture in PT. Semen Tonasa.

4. The psychological condition has a positive effect on the increasing of the knowledge and attitudes of workers in PT. Semen Tonasa.

5. There is no influence of knowledge and attitudes toward the behavior-based safety of workers in PT. Semen Tonasa.

6. There is no effect of safety culture on the knowledge and attitudes of workers in PT. Semen Tonasa.

7. Religiosity has a positive effect on the improvement of psychological conditions and also on the knowledge and attitudes of workers in PT. Semen Tonasa.

\section{References}

1. Martínez-Córcoles M, Gracia F, Tomas I, Peiró JM. Leadership and employees' perceived safety behaviours in a nuclear power plant: A structural equation model. Saf Sci 2011;49:1118-29. https://doi.org/10.1016/j.ssci.2011.03.002

2. Bodroastuti AG. Pengaruh Faktor Budaya, Sosial, Pribadi Dan Psikologi Terhadap Perilaku Konsumen (Studi Pada Pembelian Rumah Di Perumahan Griya Utama Banjardowo Semarang). Indonesia: Sekolah Tinggi IImu Ekonomi Widya Manggala; 2001. https://doi.org/10.9744/duts.4.1.40-47

3. dan Jusuf Mudzakir AM. Nuansa-nuansa Psikologi Islam. Jakarta: Grapindo Persada; 2002.

4. Ismirani M. Pengaruh Religiusitas dan adversity Question Terhadap Stress Kerja pada agen Jiwa Bersama Bumiputera 1912. Indonesia: Sikripsi Fakultas Psikologi Universitas Islam Negeri Syarif Hidayatullah Jakarta; 2011. https://doi. org/10.46899/jeps.v3i1.152

5. Krisnaldi A. Evaluasi Budaya Kesehatan Dan Keselamatan Kerja Pada Kegiatan, Thesis. Berlin: ITB; 2008.

6. Fernández-Muniz $B$, Montes-Peón JM, Vázquez-Ordás CJ. Safety climate in OHSAS 18001-certified organisations: Antecedents and consequences of safety behavior. Accid
Anal Prev. 2012;45(2012):745-8. https://doi.org/10.1016/j. aap.2011.10.002

PMid:22269566

7. Patria B. Bagaimana Behavioral Safety Mengurangi Angka Kecelakaan Kerja; 2007. Available from: http://www.inparametric. $\mathrm{com} / \mathrm{bhinablog/behavior/bagaimana-behaviouralsafety-}$ mengurangi-angka-kecelakaan-kerja. [Last accessed on 2011 Sep 20]. https://doi.org/10.31219/osf.io/r2khm

8. Siagian SP. Manajemen Sumber Daya Manusia. Jakarta: Penerbit Bumi Aksara; 2008.

9. Firmansyah FI. Analisis Pengaruh Tingkat Religiusitas Pasien Terhadap Keputusan Menggunakan Jasa Kesehatan (Studi Pada Pasien RSU PKU Muhammadiyah Roemani Semarang). Semarang: Fakultas Ekonomi Universitas Diponegoro; 2010. https://doi.org/10.37339/e-bis.v3i1.205

10. Brow TA, Littvay L, Sautter AC, Bearnes B. Ethics and personality: Emphaty and narcissism as moderator of ethical decision making in business students. J Educ Bus. 2010;85:203-8.

11. Kerja DT. Training Material Bidang Kesehatan Kerja Jakarta: Direktorat Jenderal Tenaga Kerja; 1998. https://doi. org/10.31219/osf.io/23mkn

12. Geller ES. The Psychology of Safety Handbook. USA: CRC Press LLC; 2001.

13. Dewi C. Perepsi dan Perilaku Petugas Paramedis dan Non Medis Dalam Penerapan Keselamatan dan Kesehatan Kerja (K3) di RSUD Sleman, S2 IImu Kesehatan Masyarakat (Manajemen Rumah Sakit UGM). Yogyakarta: Universitas Gadjah Mada; 2006. https://doi.org/10.31227/osf.io/vk2uf

14. Saputra AE. Faktor-faktor yang Berhubungan dengan Perilaku Aman Pengemudi Dump Truck PT.X Districk MTBU Tanjung Enim Sumatera Selatan. Indonesia: Fakultas Kesehatan Masyarakat Universitas Indonesia; 2008. https://doi.org/10.33221/jikm. v5i1.314

15. Siska O. Pengaruh Faktor Psikologis Terhadap Perilaku Konsumen Pada PT. Indonesia: Bank Muamalat Indonesia Cabang Pekanbaru, Universitas Andalas; 2009.

16. Siti A. Hubungan Antara Tingkat Pengetahuan Dengan Perilaku Pola Makan Sehat Pada Mahasiswa Kost di Kelurahan Tembalang Kecamatan Tembalang Kota Semarang, Undergraduate Thesis. Indonesia: Diponegoro University; 2007. https://doi.org/10.22435/mpk.v26i2.4163.85-92

17. Dahlawy AD. Faktor-faktor yang Mempengaruhi Perilaku Kesehatan dan Keselamatan Kerja (K3) di Area Pengolahan PT. Jakarta: Antam Tbk, Unit Bisnis Pertambangan Emas Pongkor Kabupaten Bogor, Program Studi Kesehatan Masyarakat Fakultas Kedokteran dan IImu Kesehatan Universitas Islam Negeri Syarid Hidayatullah Jakarta; 2008. https://doi. org/10.38165/jk.v6i2.148

18. Wydiyanti. Subjective well-being individu dewasa madya. $J$ Psikol. 2007;20(2):517. 